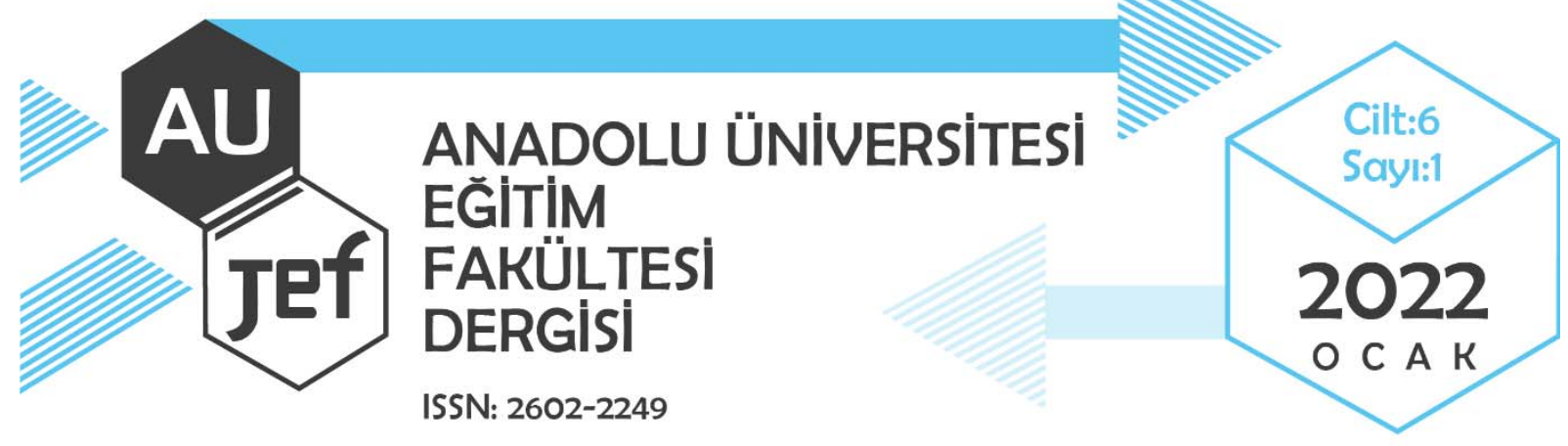

\title{
Erken Çocukluk Eğitiminde Mesleki Gelişim ve Dokümantasyonu: Öğretmen Portfolyosu
}

\section{Professional Development and Its Documentation In Early Childhood Education: Teacher Portfolio}

Ramle Gül HAZAR ${ }^{1}$, Arif YILMAZ ${ }^{2}$

Makale Türü: Derleme

Başvuru Tarihi: 20.05.2021

Kabul Tarihi: 24.01 .2022

Atıf İçin: Hazar, R. G. ve Yılmaz, A. (2022). Erken çocukluk eğitiminde mesleki gelişim ve dokümantasyonu: öğretmen portfolyosu. Anadolu Üniversitesi Ĕgitim Fakültesi Dergisi (AUJEF), 6(1), 56-77.

ÖZ: Eğitim kalitesine ilişkin beklentileri karşılamada öğretmen mesleki gelişiminin önemi dikkate alındığında, öğretmen mesleki gelişiminin etkililiğine ilişkin yaklaşımların ve gelişimi destekleyecek araçların irdelenmesinin gerekli olduğu düşünülmektedir. Erken çocukluk eğitiminde mesleki gelişim, öğretmenlerin çocuk gelişimi bilgisi, çocuklar ve ebeveynlerle etkili iletişim kurma gibi alana özgü yeterlilikleri geliştirmelerini gerektirir. Erken çocukluk eğitiminin kalitesi, eğitimcilerinin mesleki yeterliliklerini geliştirmek üzere etkili mesleki gelişim çalışmaları gerçekleştirmelerine bağlıdır. Alanyazın geleneksel mesleki gelişim çalışmalarını etkililikten uzak olarak değerlendirirken, öğretmenlerin ihtiyaçlarına hitap eden ve sınıflarında değişikliklere yol açacak etkili mesleki gelişim çalışmalarının niteliklerine odaklanmıştır. Bu doğrultuda, etkili mesleki gelişim çalışmalarının araştırma temelli olması, öğrenen çıktılarına odaklanması, iş birliği firsatları sunması, okul temelli uygulamalar içermesi, öğretmenlerin karar verme süreçlerine dahil olması, kişiye ve bağlama özgü içeriğe sahip olması ve yetişkin eğitimi prensiplerine dayanması gerektiği belirtilmektedir. Etkili mesleki gelişim çalışmaları, öğretmenlerin üstbilişsel bilgi geliştirmelerini destekler ve kendi mesleki ilerlemelerine ilişkin sorumluluk almalarını sağlayarak onları aktif bir rolde konumlandırır. Öğretmen portfolyosu, etkili mesleki gelişimin belirtilen boyutlarına zemin oluşturan bir mesleki gelişim aracı olarak karşımıza çıkmaktadır ve mesleki gelişim sürecini tanımlama ve yönetme, öğretimi geliştirme, performans değerlendirmesi, eylem araştırmaları yürütme ve mesleki yeterlikleri karşılama düzeyini gösterme için olanaklar sunar. Erken çocukluk eğitimcilerinin kendi mesleki gelişimlerinde aktif bir rol almalarını destekleyecek etkili bir araç olarak öğretmen portfolyosu geliştirmeleri, mesleki mesleki yeterliliklerini güçlendirecektir. Bu çalışmanın amacı, erken çocukluk eğitiminde öğretmen mesleki gelişimini, etkili mesleki gelişim bağlamında ele almak ve bir mesleki gelişim aracı olarak öğretmen portfolyosunu incelemektir. $\mathrm{Bu}$ çalışma, ilgili alanyazına başvurularak ve öğretmen mesleki gelişimi ile dokümantasyonuna ilişkin alanyazın ve bu konuda yapılan çalışmalar taranarak derleme türünde hazırlanmıştır. Bu derleme çalışmasında, erken çocukluk eğitiminde öğretmen mesleki gelişimi için etkili mesleki gelişim ilkeleri incelenmiş, söz konusu ilkeler doğrultusunda mesleki gelişim aracı olarak öğretmen portfolyosunun rolü değerlendirilmiştir. Ayrıca erken çocukluk eğitimcileri için öğretmen portfolyosu geliştirme süreci ile hizmet öncesi ve hizmet içi mesleki gelişimde kullanımı açıklanmıştır.

Anahtar sözcükler: Erken çocukluk eğitimi, öğretmen mesleki gelişimi, öğretmen portfolyosu

\footnotetext{
${ }^{1}$ Dr. / Bolu Abant İzzet Baysal Üniversitesi, ramlegul@ibu.edu.tr , ORCID 0000-0001-9166-2568 (Başlıca yazar)

${ }^{2}$ Dr. / Hacettepe Üniversitesi, arif@hacettepe.edu.tr , ORCID 0000-0001-5106-7721
} 
ABSTRACT: Considering the importance of teacher professional development in meeting the expectations regarding the quality of education, it is thought that it is necessary to examine the approaches regarding the effectiveness of teacher professional development and the tools that will support the development. Professional development in early childhood education requires teachers to develop domain-specific competencies such as knowledge of child development and communicating effectively with children and parents. The quality of early childhood education depends on educators' effective professional development work to improve their professional competence. While the literature consider traditional professional development activities as far from being effective, it focuses on the qualities of effective professional development studies that address the needs of teachers and lead to changes in their classroom. In this respect, it is stated that effective professional development studies should be research-based, focus on learner outputs, offer collaboration opportunities, include school-based practices, involve teachers in decision-making processes, have personal and context-specific content, and be based on adult education principles. Effective professional development studies support teachers to develop their metacognitive knowledge and position them in an active role by ensuring that they take responsibility for their own professional progress. The teacher portfolio emerges as a professional development tool that lays the groundwork for the specified dimensions of effective professional development, and offers opportunities to define and manage the professional development process, improve teaching, conduct performance evaluation, conduct action research, and demonstrate the level of meeting professional competencies. Developing a teacher portfolio as an effective tool to support early childhood educators to take an active role in their professional development will strengthen their professional professional competence. The aim of this study is to address teacher professional development in early childhood education in the context of effective professional development and to examine the teacher portfolio as a professional development tool. This study was prepared in review type by referring to the relevant literature and scanning the emphasis on teacher professional development and documentation. In this review study effective professional development principles for teacher professional development in early childhood education have been examined, and the role of the teacher portfolio as a professional development tool has been evaluated in line with these principles. In addition, the process of developing a teacher portfolio for early childhood educators and its use in pre-service and in-service professional development are explained.

Keywords: Early childhood education, teacher professional development, teacher portfolio 


\section{1. ÖĞRETMEN MESLEKİ GELIŞIMİ}

Mesleki gelişim, bir bireyin ait olduğu mesleğin uygulamalarına ilişkin ideolojik, davranışsal, entelektüel ve epistemolojik olarak gösterdiği duruştur (Evans, 2002, s. 130). Öğretmen mesleki gelişimi, öğrenenler için önemli eğitimsel çıktılar sağlamak amacıyla öğretmenlerin bilgi, beceri, tutum ve değerlerinin gelişme süreci olarak tanımlanmakta; mesleki gelişimin amaca yönelik, sürekli ve sistematik olması gerekliliği vurgulanmaktadır (Guskey, 2000). Mesleki gelişim, öğretmenlerin inanışları ve uygulamalarını etkileyerek, olumlu öğrenen çıktılarını desteklemekte, bunun yanı sıra eğitimsel reform hareketlerinde temel oluşturmaktadır (Villegas-Reimers, 2003). Eğitimsel reformlar, öğretmenlere ve eğitim yöneticilerine yeni roller ve yeni sorumluluklar edindirir. Okul düzenlemesindeki yapısal değişiklikler, alternatif okul politikaları ve karar verme süreçleri, aile ve toplumu dahil etme çabaları gibi süreçlerdeki güncellemeler eğitimcileri yaptıkları iş ile ilgili değişiklik yapmaya yönlendirir. $\mathrm{Bu}$ yeni rolleri edinip üstesinden gelebilmeleri için, mesleki gelişim her seviyedeki öğretmen ve yönetici için önem taşımaktadır (Guskey, 2000).

Guskey (2000) başlıca mesleki gelişim modellerini eğitim, gözlem / değerlendirme, gelişim sürecine katılım, çalışma grupları, eylem araştırması, bireysel yönlendirilen etkinlikler ve mentörlük olarak sıralamıştır. Lieberman (1995) mesleki gelişim çalışmalarını doğrudan öğretim, okul temelli öğrenme ve okul dışı öğrenme olmak üzere üç başlık altında sınıflamıştır. Doğrudan öğretim modelleri konferans ve kurslar gibi etkinliklerdir. Bu tür etkinlikler önemli olmakla birlikte sinıf ile ilişkilendirilmedikleri sürece gelişim sağlamaları zordur. Okul temelli öğrenme modelleri eylem araştırması, akran koçluğu, mesleki yazı yazma, öğretmen liderliği, problem çözme grupları, portfolyo değerlendirmesi gibi çalışmalardır. Bu tür çalışmalar uygulamaya dönük olduğu için öğretmenlerin mesleki uygulamalarında gerçek değişiklikler yapmalarına olanak tanır. Okul dışı öğrenme modelleri ise okul-üniversite iş birliği, informal gruplar, öğretmen merkezleri gibi uygulamaları içermektedir. $\mathrm{Bu}$ tür uygulamalar öğretmenlerin çalıştıkları okul dışında gerçekleştiği için okullarında eriştiklerinden daha farklı nitelikte mesleki öğrenme firsatları sunar (Lieberman, 1995). Mesleki gelişim modelleri erken çocukluk eğitimcileri özelinde incelendiğinde, başvurabilecekleri mesleki gelişim etkinliklerinin oldukça geniş çeşitlilikte olduğu görülmektedir. Öğretmenlerin kendilerinin başlatabilecekleri öz değerlendirme, mesleki okuma, eylem araştırması, yeni bir girişime liderlik etme; sınıflarıyla ilişkili olan kurslar, çalıştaylar, konferanslar, seminerler, yeterlik programları, açık ve uzaktan eğitim; akran eşliğinde gerçekleştirilen okul ziyaretleri, mesleki ağlara katılım, akran gözlemi, informal diyaloglar, işbirlikli araştırmalar veya liderlik aktiviteleri olarak mentörlük, öğretmen araştırmalarına danışmanlık, değişim programları gibi çeşitli mesleki gelişim stratejileri mevcuttur (MSF, t.y.). Mraz ve Kıssel (2014) ise erken çocukluk mesleki gelişim modellerini koçluk, sınıf içi mentörlük, mesleki öğrenme toplulukları ve dijital / web tabanlı koçluk başlıkları altında ele almıştır.

Erken çocukluk eğitimcileri küçük çocukları formal eğitime hazırlama ve yaşam boyu sürdürecekleri öğrenmeye karşı olumlu tutum kazandırma sorumluluğu altındadır (NBPTS, 2012). Erken çocukluk eğitimcilerinin bilgi, beceri ve uygulamaları, bir çocuğun ne kadar öğrendiğini ve okul hayatına ne kadar hazır olduğunu belirlemede önemli bir faktördür. Erken çocukluk eğitimcilerinin söz konusu mesleki uygulamalarının niteliğini arttırmak amacıyla mesleki gelişimlerine yönelik yapılan yatırımlar, eğitim kalitesinin göstergesidir (Elliott, 2002; Martinez-Beck \& Zaslow, 2006; Sheridan, 2009). Çocuklara ve ailelere kaliteli erken çocukluk eğitimi hizmeti sunmak için erken çocukluk eğitimi işgücünde mesleki gelişim esastır (NAEYC \& NACCRRA, 2011). Erken çocukluk eğitiminde mesleki gelişim, devam eden deneyimlerin sağladığı gelişmenin yanı sıra, eğitimcileri çocuklar ve aileleri için ve onlarla çalışmaya hazırlamak amacıyla tasarlanan öğrenmelerin ve destekleyici etkinliklerin sürekliliğidir. Mesleki gelişim erken çocukluk eğitimcilerinin artan bilgi ve becerileriyle inşa ettikleri kariyerleri boyunca tüm rollerde ilerlemelerini sağlar (National Association for the Education of Young 
Children \& National Association of Child Care Resource \& Referral Agencies / NAEYC \& NACCRRA, 2011). Erken çocukluk alanında mesleki gelişim yoluyla eğitimcilerin beşerî ve sosyal sermayelerinin geliştirilmesi, çocuk çıktılarının desteklemesi ve öğrenme ortamlarının kalitesinin artırılması temel hedeflerdir. (Zaslow vd., 2010).

\subsection{Etkili Mesleki Gelișim}

Son yıllarda araştırmalar, öğretmenlerin mesleki öğrenmesi için güçlü firsatlar sunan ve geleneksel modelden ayrılan yeni bir paradigma olarak etkili mesleki gelişim kavramı üzerine yoğunlaşmıştır (Bümen vd., 2012; Can, 2019; Elçiçek ve Yaşar, 2016; Griffith vd., 2014; İlğan, 2013; Zaslow vd., 2010; Wells, 2014). Etkili mesleki gelişim öğretmenlerin bilgilerinde, uygulamalarında ve öğrenen çıktılarında değişikliklerle sonuçlanan, yapılandırılmış mesleki öğrenme süreçleridir (DarlingHammond vd., 2017). Bir diğer ifadeyle "öğretmenlerin belirli ihtiyaçları doğrultusunda mesleki ilerleme sağlayacaklarını taahhüt etmeleri” olarak tanımlanan (Diaz-Maggioli, 2004, s.5) etkili mesleki gelişim, öğretmenleri kendi mesleki ilerlemelerinden sorumlu bireyler olarak konumlandırmıştır.

Mesleki gelişim alanyazını, geleneksel yaklaşımdan uzaklaşarak etkili mesleki gelişim bakış açısına yönelirken, araştırmacılar tarafından etkili mesleki gelişimin tanımını derinleştirecek çeşitli özellikler vurgulanmıştır. Guskey (2003), 13 farklı eğitim birliğinin oluşturduğu etkili mesleki gelişim özellikleri listelerini inceleyerek bu listelerdeki ortak vurguları şu şekilde belirlemiştir; araştırma temelli olma, alan ve pedagoji bilgisi, yeterli zaman ve kaynak, iş birliği, değerlendirme, okul temelli olma, öğrenen çıktıları. Diaz-Maggioli (2004)'nin “vizyoner mesleki gelişım” olarak tanımladığı çağdaş yaklaşım; öğretmenlerin karar verme süreçlerine katılımı, mesleki gelişim odaklı bakış açısı, programların kolektif yapılandırılması, araştırma temelli fikirler, kişiye özgü içerik, çeşitli ve doğru zamanda uygulanan yöntemler, yeterli destek sistemleri, bağlama özgü içerik, proaktif değerlendirme ve andragojik eğitim unsurlarını içermektedir (s.6). Etkili mesleki gelişimin özelliklerini tanımlamak için Desimone (2009) 5 ana unsur olarak; alana özgü içerik, aktif öğrenme, uyumluluk, yeterli öğrenme süresi ve toplu katılımı belirlemiştir. Darling-Hammond, Hyler ve Gardner (2017) ise bu çerçeveyi genişleterek etkili mesleki gelişimin ilkelerini; alana özgü içerik, yetişkin eğitimi teorilerine dayanan aktif öğrenme, işe gömülü bir bağlamda iş birliği, etkili uygulama örnekleri, koçluk ve uzman desteği, geri bildirim ve yansıtma, sürdürülebilirlik olarak tanımlamışlardır. Patton, Parker ve Tannehill (2015) etkili mesleki gelişimin temel özellikleri için 8 madde belirlemiş ve bu özellikleri öğretmen katılımı, öğretim uygulaması ve öğrenen çıktısı boyutları ile Şekil 1'de gösterildiği gibi ilişkilendirmişlerdir. 


Öğretmen katılımı ile
ilişkili özellikler
•Mesleki gelişim
öğretmenlerin
ihtiyaçlarına ve
ilgilerine dayanır.
-Mesleki gelişim
öğrenmenin sosyal bir
süreç olduğunu kabul
eder.
-Mesleki gelişim
eğitimcilerin öğrenme
topluluklarında işbirlikli
fursatları içerir.
-Mesleki gelişim
süregelen ve
sürdürülebilirdir.
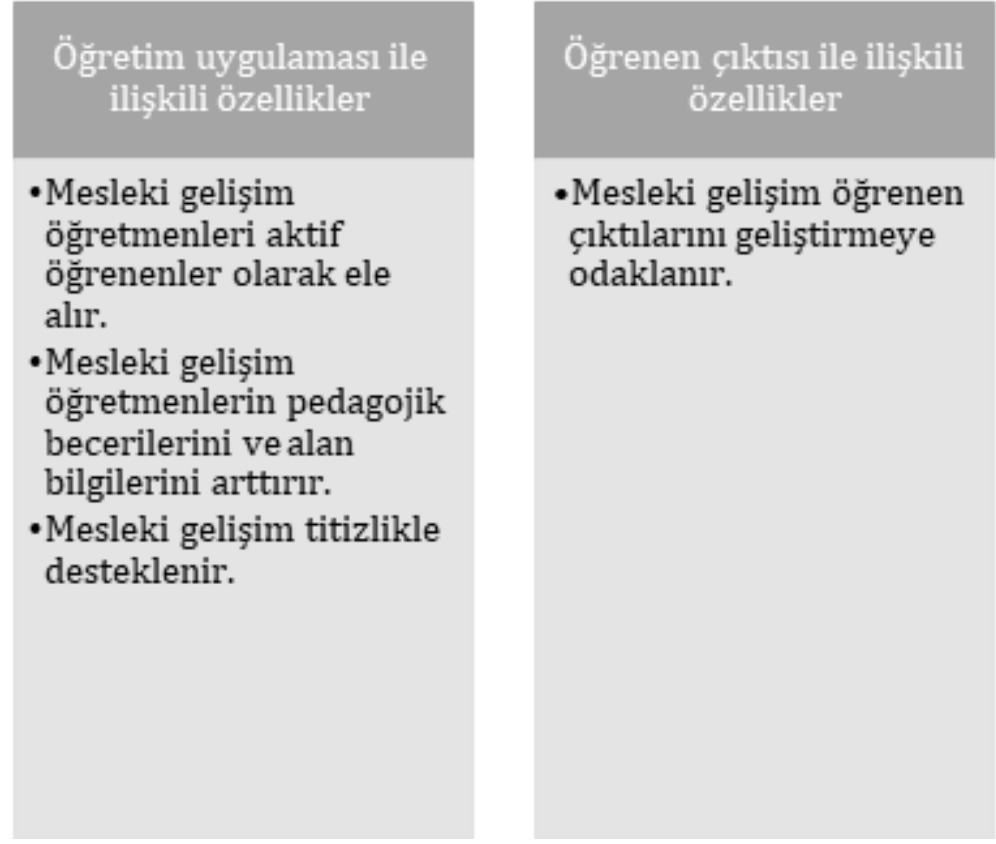

Şekil 1: Etkili Mesleki Gelişimin Özellikleri

Genel olarak etkili mesleki gelişim yaklaşımı öğretmenlerin neyi ne zaman ve nasıl öğrendiğine odaklanarak, öğretmenleri denetlemeden ve yönlendirmeden, öğrenen çıktılarından sorumlu kılar. Etkili mesleki gelişim yaklaşımı, politika yapıcıların yukarıdan aşağıya uygulanmasını öngördüğg̈ çözümler yerine, öğretmenlerin kendi bağlamlarında yapılandırdıkları ve kullandıkları çözümlere odaklanır. Mesleki gelişime ilişkin araştırmalardan elde edilen tecrübeler, öğretmen niteliğini artmasıyla gerçekleşecek eğitim reformu sağlamak, başka bir ifadeyle "aşağıdan yukarıya bir değişim" elde etmek için mesleki gelişimde öğretmen odaklı bir bakış açısına dikkat çekmektedir. Bu bakış açısı üst kademelerdeki eğitim yöneticilerinin mesleki gelişim çalışmalarına ilişkin tepeden inme kararlarla yukarıdan aşağıya destek sağlama çabalarına karşın yol gösterici ilkeler sunmaktadır (DarlingHammond \& McLaughlin, 2011).

Etkili mesleki gelişimin belirtilen unsurları öğretmenleri, geleneksel mesleki gelişim yaklaşımının yerleştirdiği pasif rolden uzaklaştırarak, kendi mesleki öğrenme süreçlerinde daha aktif bir role yerleştirmektedir (Youngs \& Lane, 2014). Mesleki gelişimde etkililiği sağlamak için öğretmenlerin yetkilendirilmesi ve öğretmen liderliğinde mesleki gelişim yaklaşımının benimsenmesi gerekir (Stacy, 2013). Öğretmenlerin kendi mesleki gelişimlerinde yetki sahibi olmaları, yeni fikirlere karşı savunma bariyerlerini indirmeleri ve kendi düşüncelerini açıkça ortaya koymaları için firsatlar sunar. Bu yolla öğretmenler mesleklerine ilişkin olarak gurur, sahiplik ve sorumluluk duyguları geliştirirler. Öğretmeni kendi mesleki gelişiminde yetki sahibi kılmak, eğitimsel ufuklarının genişlemesini destekleyerek mesleki gelişim çabaları için motivasyon sağlar (Wells, 2014).

Öğretmenlerin kendi mesleki gelişim süreçlerinde aktif rol alarak öğretmen liderliğinde mesleki gelişim süreçleri yönetmelerinde, öz düzenleyici öğrenme önemli bir rol oynar. Öz düzenleyici mesleki öğrenme, öğretmenin özerk ve kasttlı olarak kendi mesleki öğrenme hedeflerine ulaşmak üzere çaba göstermesini ifade eder. Öz düzenleyici mesleki öğrenme planlama, görünür kılma ve değerlendirme aşamalarını içerir (Janssen, Kreijns, Bastiaens, Stijnen \& Vermeulen., 2012; Peeters, Backer, Reina vd., 2014; Van Eekelen, Boshuizen, \& Vermunt, 2005). Öğretmenlerin söz konusu aşamaları takip ederek öğretmen liderliğinde mesleki gelişim gerçekleştirmelerinde, öğretmen portfolyosu etkili bir mesleki gelişim aracı olarak karşımıza çıkmaktadır (Aras, 2019; Janssen vd., 2012) çünkü öğretmen portfolyosu, 
öğretmenin mesleki yeterliliğine dair kanıtlar yoluyla kendi öğretimine ilişkin farkındalık elde etmesini ve yansıtma yapmasını sağlayarak mesleki gelişime ilişkin karar alma süreçlerini destekler. Öğretmenler portfolyo geliştirirken özerk öğrenenler olarak, mesleki gelişim çalışmalarının içeriğini, çerçevesini ve amaçlarını kendileri belirlerler. Planlanan bu mesleki gelişim süreci boyunca öğretmenin sınıf içindeki uygulamalarının etkililiğine ilişkin elde ettiği kanıtlar ve yaptığı yansıtmalar mesleki öğrenmesini teşvik eder (Campbell vd., 2014).

\section{2. ÖĞRETMEN PORTFOLYOSU}

Öğretmen portfolyosu öğretmenlerin bilgi, beceri ve tutumlarına ilişkin kanıtlar sağlayan belgelerin, belirli hedefler doğrultusunda düzenlenerek bir araya getirilmiş halidir. Öğretmen portfolyosu, bir öğretmenin performansına ilişkin gerçek bir resim sunarak, öğretmenin kendi öğretimi üzerine derinlemesine düşünmesini teşvik eder (Costantino \& De Lorenzo, 2009). Öğretmen portfolyosu öğretmenlerin kendi performanslarına ilişkin belge ve materyalleri arşiv niteliğiyle biriktirmesi değil, öğretim süreçlerinin niteliğine ilişkin güvenilir kanttların özenle seçimi ve sunumudur (Kaplan, 1999; Bullock \& Hawk, 2010; Paul, 2004). Öğretmen portfolyosu yoluyla öğretmen performansına ilişkin sunulan iddialar sağlam kanıtlarla desteklenmelidir. Seçilen kanıtlar, öğretmenin performansına ilişkin mantıkl1, eleştirel ve anlamlı bir analiz sağlar (Seldin, Miller \& Seldin, 2010).

Portfolyoda yer alacak belgelerin oluşturulması veya seçimine, öz değerlendirme ve yansıtma süreçleri eşlik etmelidir (Costantino \& De Lorenzo, 2009). Portfolyo, öğretmenlerin uygulama deneyimleri üzerine düşünmelerini ve mesleki bilginin ifade edilmesini teşvik ederek yansitma uygulamaları gerçekleştirmelerini sağlar (Chetcuti, Buhagiar \& Cardona, 2011). Yansıtma süreci, öğretmenlerin eylemlerini yakaladıkları ve yönlendirdikleri bir analiz sürecidir. Öğretmenler bu yolla kendi çalışmalarından yola çıkarak teori ile uygulama arasında ilişkiler kurabilirler (Garcia vd., 2006). Öğretmen portfolyosu, öğretmenlerin mesleki uygulamalarını tanımlama, analiz etme ve gelecek uygulamalarını şekillendirme aşamalarını izleyerek yansıtma yoluyla mesleki gelişim sağlamalarına zemin oluşturur (Bullock \& Hawk, 2010).

\subsection{Hizmet Öncesi ve Hizmet İçi Öğretmenler İçin Öğretmen Portfolyosu}

Öğretmen adaylarının ve görev yapan öğretmenlerin geliştirdikleri çeşitli portfolyo türleri mevcuttur. Öğretmen adaylarının ve hizmet içi öğretmenlerin mesleki gelişim amacıyla geliştirdikleri çalışma portfolyoları çeşitli kaynaklarda (Jones \& Shelton, 2011; Wiltz vd., 2013; Wray, 2004) gelişimsel portfolyo, süreç portfolyosu veya mesleki portfolyo olarak da tanımlanmaktadır.

Öğretmen adaylarının lisans eğitimi süreçlerinde, öğrenenlerin kendi bilgilerini yapılandırdıkları yapılandırmacı yaklaşım ve öğrenen merkezli öğrenmeyle ilgili edindikleri farkındalıklarını, kendi mesleki öğrenme süreçlerine de transfer etmeleri önemlidir. Öğrenen merkezli yaklaşımla öğrenenler seçim yapmaları, materyalleri keşfetmeleri ve problem çözmeleri için teşvik edilir. Öğretmen portfolyosu geliştirme süreci, öğretmen adaylarının birer eğitimci olarak kendilerine ilişkin bilgiyi oluşturdukları yapılandırmacı bir etkinliktir (Friedman, 2012). Öğretmen adaylarının geliştirdikleri portfolyo türleri; bir programa kabul edilmek için giriş portfolyosu, program gereklilikleri doğrultusundaki mesleki gelişimini desteklemek üzere çalışma portfolyosu, programdan mezun olma aşamasında sahip olduğu yeterlikleri belgelendirmek amacıyla mezuniyet portfolyosu ve çalışma ve mezuniyet portfolyolarından seçilmiş sınırlı sayıda unsur ile oluşturulan ve iş başvurularında kullanmak üzere hazırlanan görüşme portfolyosudur (Costantino \& De Lorenzo, 2009). Öğretmen portfolyosu geliştirme süreci, öğretmen adaylarının mesleği anlamalarına, öz farkındalık geliştirmelerine, kariyer 
gelişimlerini tasarlamalarına, bütüncül ve otantik değerlendirme süreçlerine olanak sağlar (Campbell vd., 2014). Öğretmen adayları portfolyo geliştirirken yaptıkları çalışmaları gözden geçirir, her bir çalışmayı gerçekleştirirken neler öğrendiği ve mesleki olarak nasıl değiştiği üzerine düşünür. Ayrıca mesleki gelişim sağlamak için bir öğretmen olarak neler öğrenmek istediğini belirler. Öğretmen portfolyosu öğretmen adaylarının kendi gelişimlerini izleyerek öz değerlendirme yapmalarına olanak sağlar. Geliştirilen portfolyolar, öğretmen adaylarının kariyer geleceklerini planlamak üzere öğretim üyeleri ile diyalog kurmak için bir temel oluşturur (Friedman, 2012).

Hizmet içi öğretmenler için öğretmen portfolyosu, yürütülmekte olan öğretim tarzını değiştirmek için bir araçtır. Kanıt temelli dokümantasyon ile elde edilen gerçek profil, öğretmenlerin öğretim süreçlerinin etkililiğine ilişkin otantik ve bütüncül değerlendirme sağlar. Öğretmen portfolyosu uygulama yapan öğretmenleri eğitim felsefelerini ve hedeflerini iyileştirmek ve öğretimin niteliğini arttırmak için bir katalizör görevi görür. Portfolyo geliştirmek, mesleki performansı görünür ve paylaşılabilir hale getirerek okul yöneticileri veya daha deneyimli öğretmenlerden destek almak için bir fırsat sağlar, böylece öğretmenler arasında etkileşimi ve iş birliğini destekler. Bunun yanında mesleki gelişim sürecini tanımlama ve yönetme, öğretimi geliştirme, performans değerlendirmesi, eylem araştırmaları yürütme ve mesleki yeterlikleri karşılama düzeyini gösterme için olanaklar sunar (Campbell vd., 2014). Görev yapan hizmet içi öğretmenlerin geliştirdikleri portfolyolar, mesleki gelişim hedefleri ile bağlantılı olan mesleki performans ve başarılarını belgelendirdikleri çalışma portfolyosu ile iş arkadaşları, yöneticiler, ebeveynler ve toplum üyeleri ile paylaşılmak üzere geliştirilen örnek niteliğinde seçilmiş kanıtların gösterildiği sergi portfolyosudur (Costantino \& De Lorenzo, 2009).

\section{2. Öğretmen Portfolyosu Neden Gerekli?}

Öğretmen portfolyosunun, yetişkin öğrenenler olarak öğretmenleri çeşitli yollarla desteklediği ifade edilmektedir. Öğretmen portfolyosu öncelikle, öğretmenlere kendi öğrenmeleri için sorumluluk yükler ve kendilerini öğrenen olarak nasıl tanımladıklarını belirlemelerine yardımcı olur. Ayrıca, öğretmenlerin teorik altyapılarını mesleki uygulamalarına yansıtmaları için fırsat sunar ve öğretmenlerin eğitime ilişkin bakış açılarının genişlemesini destekler. Öğretmen portfolyosunun bir diğer yararı ezbercilikten uzak, kalıcı ve anlamlı mesleki öğrenme sağlamasıdır; bu süreçte öğretmenler deneme yanılmalar yaşar, meslektaşlarıyla diyaloglar kurar ve bildiklerini, bunları nasıl öğrendiğini ve kendisini nasıl etkilediğini düşünür ve sorgular. Son olarak portfolyo geliştirme süreci üstbiliş, soyut ve karmaşık düşünce, kuramsal muhakeme gibi işlevsel düşünce becerilerini güçlendirir. Bu bilişsel beceriler öğretmenlerin mesleki öğrenmelerini içselleştirmelerinde ve daha üst düzey beceriler geliştirmelerinde rol oynar (Jones \& Shelton, 2011). Smith ve Tilemma (2010) öğretmen portfolyosunun uzun vadeli etkilerini; mesleki yeterliklerin ve gelişimin dokümantasyonu, sistematik kendini yansıtma, meslektaşlarla yansıtıcı diyalog gerçekleştirme ve analitik düşünerek hatalardan ders alma olarak sıralamışlardır. Bu bağlamda, öğretmen portfolyosunun mesleki gelişim çalışmalarına ilişkin kayıt tutmanın ötesinde, mesleki yeterlilikleri çok yönlü bir şekilde desteklediği görülmektedir.

Mesleki öğrenme portfolyosu olarak da tanımlanan öğretmen portfolyosunun, başarılara ilişkin kayıtların tutulduğu özgeçmiş dosyalarından ayrılan yönü mesleki gelişimi destekliyor oluşudur. Öğretmen portfolyosu mesleki gelişimde "yansıtma yoluyla mesleki öğrenme" sağlar (Retallick, 2000; akt. Dinham \& Scott, 2003). Mesleki ilerlemenin bir portfolyo kapsamında belgelenmesi ve ardından bunun üzerine yansıtma yapılması, öğretmenin kendi öğrenmesini geliştirmesinin ve profesyonel öğrenmenin gerçekleştiğini başkalarına göstermesinin bir yoludur. Öğretmen portfolyosu, hem geliştiren kişinin hem de portfolyoyu inceleyen diğer kişilerin zaman içinde öğretmenin mesleki 
öğrenimi hakkında yargılarda bulunmasını sağlar. Bu yönüyle portfolyo, kişinin profesyonel başarısı için hem bir ölçüt hem de rehberdir (Dinham \& Scott, 2003).

Öğretmen portfolyosu her kademeden öğretmenin kullanabileceği bir araç olmakla birlikte küçük çocuklarla çalışan eğitimcilerin çok yönlü mesleki gelişimlerine rehberlik etmektedir. Erken çocukluk eğitimi mesleki gelişiminde öğretmenler, kendi öğretim uygulamaları üzerinde düşünmeye, ihtiyaç değerlendirmesi yapmaya ve mesleki gelişimlerini planlamak için rehberliğe ihtiyaç duyarlar. Öğretmen portfolyosu, erken çocukluk eğitimcilerinin hem teorik hem de uygulama temelinde söz konusu ihtiyaçlarına ayrıntılı bir şekilde karşılık veren bir yapıya sahiptir (Aras, 2021). Goodfellow (2004) öğretmen portfolyosunun erken çocukluk eğitimcileri için sağladığg destekleri şu şekilde sıralamıştır; erken çocukluk eğitiminde önemli uygulamalara ilişkin öğretmenin kendi uygulamalarının güçlü ve gelişime açı yönlerini gösterme, sınıftaki uygulamalarla ilgili analitik ve yorumlayıcı kayıtlar sunma ve böylece eleştirel düşünme becerilerini destekleme, mesleki büyümeyi betimleme ve kişinin kendi mesleki gelişimini ilerletmek için bir temel oluşturma, bir profesyonel olarak çalışmalarının amacını belgeleme. bu açıdan değerlendirildiğinde öğretmen portfolyosunun erken çocukluk alanında çalışan eğitimcilerin mesleki gelişimleri için temel bir araç olma özelliği taşıdığı görülmektedir.

\subsection{Mesleki Gelişimde Öğretmen Portfolyosunun İşlevleri}

Öğretmen portfolyosunun mesleki gelişimi planlama, belgelendirme, değerlendirme ve karar alma aşamalarına nasıl hizmet ettiği aşağıda ele alınmıştır.

\subsubsection{Planlama}

Öğretmenler portfolyo geliştirirken, özerk öğrenenler olarak mesleki gelişim süreçlerini planlayarak mesleki çalışmalarının içeriğini, çerçevesini ve amaçlarını kendileri belirlerler (Campbell vd., 2014; Costantino \& De Lorenzo, 2009). Öğretmen portfolyosunun yapılandırıldığı bölüm olan mesleki gelişim planı (Janssen vd., 2012) öğretmenlerin oluşturdukları ve sürekli olarak gözden geçirerek güncelledikleri, ileriki mesleki gelişimlerini yönlendirecek bir belgedir. Mesleki gelişimin planlanması, mesleki standartları veya yeterlilikleri karşılamak üzere kişisel ve mesleki amaçların belirlenmesi sürecidir. Bireysel mesleki gelişim planı, eğitimcilerin mesleki karar verme ve hedef belirleme süreçlerinde aktif rol almalarını gerektirir ve sorumluluk almalarını destekler (Sugarman, 2011). Mesleki gelişimi planlama süreci öğretmenin öz değerlendirme yoluyla güçlü ve zayıf yönlerini keşfetmesi, bu doğrultuda mesleki öğrenme hedeflerini belirlemesi ve son olarak hedeflere ulaşmak üzere izleyeceği eylem planını oluşturması olmak üzere üç adımda gerçekleşir (Janssen vd., 2012). Mesleki gelişim planı geliştirmede ilk adım olan öz değerlendirme, mesleki büyüme için oldukça güçlü bir tekniktir. Öğretmenlerin öz değerlendirme yoluyla kendi etkililiklerinin farkına varmaları, hedef belirlemelerini ve mesleki gelişim için çaba harcamalarını teşvik eder (Ross \& Bruce, 2007). İkinci adım olan hedef belirleme, öğretmenlerin teori veya uygulamaya ilişkin değiştirmek istedikleri davranış, düşünce, inanış, eğilimlerini kapsamaktadır (Louws vd., 2018). Son adım, belirlenen hedeflere ulaşmak için gerçekleştirilecek öğrenme etkinliklerinin; başvurulacak stratejiler, kullanılacak kaynaklar ve zamanlama gibi detaylarla açık bir şekilde belirlenmesidir (Janssen vd., 2012; Sugarman, 2011).

\subsubsection{Dokümantasyon}

Mesleki gelişim çalışmalarının etkililiğini sağlamak için sürecin planlaması ve uygulanması kadar belgelendirilmesi de önem taşımaktadır (Buldu \& Üstebay Aras, 2014). Öğretmenler, gelişen meslek 
elemanları olarak mesleki performanslarını, bilgi, beceri ve tutumlarını öğretmen portfolyosu geliştirerek somut kanıtlarla belgelendirebilirler (Campbell vd., 2014). Öğretmen portfolyosuyla sistematik dokümantasyon yapmak, öğretmenlerin kendi uygulamaları hakkında daha bilinçli olmalarını ve önceki uygulamalarına ilişkin yansıtma yapmalarını sağlar (Aras, 2019), ayrıca mesleki uygulamaların zorluğunun anlaşılmasına olanak tanır (Goodfellow, 2004).

Portfolyo hazırlamanın belirli bir formülü yoktur ve hazırlanan iki portfolyo birbirinden tamamen farklı olabilir, çeşitli biçimlerde ve boyutlarda hazırlanabilir. Öğretmen bireysel etkinliğine dair kanıtları seçerken kendi özgün resmini ortaya koyar (Bullock \& Hawk, 2010; Wiltz vd., 2013). İyi geliştirilmiş, kapsamlı ve etkin bir portfolyo, tek başına, başarılı öğretimin nasıl olacağına dair net bir resim sağlayabilir (Campbell vd., 2014). Etkili bir öğretmen portfolyosunda iki ana dokümantasyon unsuru, uygulama kanitları ve yansitıc ifadelerdir (Paul, 2004).

Uygulama kanıtları, bir diğer ifadeyle ürünler şunlar olabilir (Campbell vd., 2014); eylem araştırmaları, uyarlamalar, anekdot kayıtları, öğrenenlerin gelişim ve öğrenmesine ilişkin değerlendirme örnekleri, ödüller, sertifikalar, sınıf yönetimi stratejileri, program planları, bireyselleştirilmiş eğitim planı, ailelerle iletişim yolları, aile görüşmelerinin özetleri, toplantılar, atölye çalışmaları, iş arkadaşlarının değerlendirmeleri, eğitim felsefesi, fotoğraf ve videolar, çocukların gelişim ve ögrenmelerinin değerlendirilmesine olanak sağlayan öğrenen portfolyoları, mesleki gelişim planı, mesleki okuma listesi, projeler, kaynaklar, araştırma makaleleri, rubrikler, öz değerlendirme araçları, yansitıcı günlükler, öğrenenlerle etkileşimler, öğretmenin yaptığı materyaller, teknolojik kaynaklar.

Portfolyoda yer alan ürünlerin, açıklama ve yansıtma ifadeleri ile desteklenmesi gerekir. Açılamalarda ürünün seçilme gerekçesine, etkinliğin tasvirine, öğretmen ve öğrenenlerin yaşanan deneyimden elde ettikleri öğrenme çıktılarına yer verilir. Yansıtma ise öğretmenlik mesleği ile ilgili konular hakkında daha dikkatli ve analitik bir düşünme süreci gerektirir. Öğretmenin "ne yaptığı", "neden yaptığı", "nasıl yaptı̆̆ı”, ve "öğretimin öğrenenler üzerindeki etkisi” ile ilgili ifadeler içerir. Yansıtmalar performans dokümantasyonunu anlamlı hale getirir. Yansıtmanın amacı, öğretmenin kendi düşünceleri, duyguları, öğretim ile ilgili kararları ve öğrenenlerin tepkilerine ilişkin farkındalığını geliştirmektir. Etkili bir yansıtma süreci şu adımları içerir; tanımlama (bir öğretme deneyiminin tanımlanması), tasvir (öğretmenin neyi, neden ve nasıl yaptığı, öğrenenler üzerindeki etkisi), analiz (öğretmenin bu deneyime ilişkin duygu ve düşünceleri), genelleme (bu deneyimden öğrenilenler), eylemler (gelecekte yapılacak farklı uygulamaların açıklanması), yansıtma (tüm süreci içeren, ürüne ilişkin bir yansıtmanın yazılması) (Costantino \& De Lorenzo, 2009).

Portfolyo ürünlerini toplama, gözden geçirme ve ürünlere ilişkin yansıtma yapma, öğretmenler için yenilenme ve mesleki tatmin sağlar. Mesleki uygulamaları sürdürürken, mesleki başarıya dair büyük resmi görmek zor olabilir. Bir portfolyoyu bütünüyle tamamlamak öğretmeni; planlama yapma, ürün oluşturma, değerlendirme ve yansıtmaya zorlar. Öğretmenler, portfolyo geliştirerek yenilenme hissine ulaşır ve gelişim alanlarına ilişkin tatmin sağlarlar (Costantino \& De Lorenzo, 2009).

\subsubsection{Değgerlendirme ve Karar Alma}

Portfolyo gelişimine öncülük eden mesleki gelişimin planlanması süreci öğretmenlerin öz değerlendirme yapmalarını gerektirmektedir (Janssen vd., 2012). Öz değerlendirme, mesleki ilerlemeyi izleme ve ileriye dönük kararlar almaya firsat sağladığı için mesleki gelişimde önemli bir yere sahiptir (Friedman, 2012; Ross \& Bruce, 2007). Öğretmenler portfolyo oluşturma sürecinde ürün seçerken veya çalışmalarına ilişkin yansıtma yaparken, doğal olarak bu ürünleri gözden geçirerek değerlendirme sürecine girmiş olurlar (Friedman, 2012). Öğretmen portfolyosu, öğretmenlere kendi mesleki 
gelişimlerini yönlendirme olanağı tanır. Öğretmenler, portfolyoda yer alan kanıtlara dayalı olarak gelecek mesleki gelişimlerini planlarlar. Kanıtlara dayalı planlama, öğretmenlerin mesleki ihtiyaçlarını karşılanmasına öncülük ederek sürecin etkililiğini arttırır (Aras, 2019).

Portfolyo, geleneksel değerlendirme yöntemlerinde gözden kaçırılan verilere dair çoklu kaynaklar sağlar ve bu yönüyle öğretmenin gelişim ve öğrenmesine ilişkin oldukça özgün bir değerlendirme aracıdır. Standart testlerde öğretmen var olan performansını tam olarak sergileyemeyebilir. Portfolyo, öğretmen performansını diğer geleneksel değerlendirme yöntemlerine göre daha derinlemesine ele alır (Costantino \& De Lorenzo 2009) ve öğretmenlerin düşüncelerinin ve inanışlarının iç yüzünün anlaşılmasını sağlar (Westhuizen \& Smith, 2000).

Otantik değerlendirme aracı olarak portfolyo, ürünler ve yansıtmalar doğrultusunda öğretmenin kendi ilerlemesini ve gelecek mesleki gelişim hedeflerini belirlemesine olanak tanıarak biçimlendirici değerlendirme sağlar. Öğretmenler, süreç içindeki mesleki gelişimini portfolyo sunumu ile bir grupla paylaşarak mesleki profilini çıkarır ve bu noktada da sonuç değerlendirme yapılmış olur. Portfolyo yalnızca öğretmenin gelişimi desteklemekle kalmaz, aynı zamanda program değerlendirme için de önemli bilgiler sağlar (Seldin vd., 2010; Wiltz vd., 2013).

\section{4. Öğretmen Portfolyosu Organizasyonu}

Öğretmen portfolyosu, öğretmenin performansına ilişkin anlık bir görüntü sağlamanın ötesinde mesleki gelişim sürecindeki ilerlemesini izlemeye hizmet eden bir araç olarak görülmektedir. $\mathrm{Bu}$ yönüyle portfolyo, bağlam ve zaman doğrultusunda sürekli değişen dinamik bir yapıya sahiptir. Dolayısıyla portfolyo organizasyonu bu dinamik yapıyı destekler nitelikte gerçekleştirilmeli ve zamanla gelişen ve düzenlemelere tabi tutulan içerik unsurları için uygun bir zemin oluşturmalıdır. Tucker, Stronge ve Gareis (2002) etkili bir öğretmen portfolyosu düzenlenmesi için portfolyo içeriğinin ilişkilendirileceği yeterlikler ve portfolyo içeriğinde bulunması gereken unsurlar olmak üzere iki boyutun ele alınması gerektiğini ifade etmiştir.

Dünyada erken çocukluk eğitimcilerinin mesleki gelişim süreçlerinde temel aldıkları, çeşitli mesleki kuruluşlar tarafından oluşturulmuş performans alanlarının ve standartların yer aldığı çerçeveler mevcuttur (InTASC, 2013; NAEYC, 2011; NBPTS, 2012). Ülkemizde ise Millî Eğitim Bakanlığ1 tarafından Öğretmenlik Mesleği Genel Yeterlikleri (MEB, 2017) belirlenmiş ve mesleki gelişimde referans noktası olarak başvurulmak üzere tüm alanlardaki öğretmenlerin ve öğretmen eğitimcilerinin kullanımına sunulmuştur. Portfolyoyu düzenlerken belirli gelişim alanlarını temel almak ve böyle bir düzende mesleki öğrenme çıktıları ile mesleki standartları ilişkilendirmek mesleki gelişim sağlamak için etkili bir yoldur (Campbell vd., 2014; Wiltz vd., 2013). Mesleki yeterlik alanları ve basamakları, mesleki gelişimin seviyelerini ve uzmanlaşma adımlarını anlamak bakımından önem taşır, mesleki gelişimin sistematik olarak organize edilmesine olanak tanır, öğretmenlerin gelişime açık alanlarını analiz etmelerini destekler ve kendini izleme becerilerini geliştirir (Sultana, 2009). Söz konusu çerçeve yapılar, mesleki gelişimin planlama aşamasından itibaren göz önünde bulundurulmalı ve mesleki gelişimin dokümantasyon ve değerlendirme süreçlerine de rehberlik etmelidir.

Erken çocukluk eğitimi alanına yönelik mesleki yeterlik alanlarını; Ulusal Çocuk Eğitimi Derneği (National Association for the Education of Young Children, NAEYC) gelişim ve öğrenme, program ve içerik bilgisi, aile ve toplum ilişkileri, çocuklar ve ailelerle etkili iletişim, gözlem, dokümantasyon ve değerlendirme ve mesleki gelişim olmak üzere 6 boyutta belirlemiştir (NAEYC, 2011). Mesleki Öğretim Standartları için Ulusal Kurul (National Board for Professional Teaching Standards NBPTS)'un erken çocukluk uzmanları için belirlediği standart alanları ise gelişim bilgisi, alan bilgisi, 
gelişim ve öğrenme için planlama, gelişim ve öğrenme için çevreyi düzenleme, gelişim ve öğrenme için öğretimi uygulama, aile ve toplumla iş birliği, çocukların gelişim ve öğrenmesini değerlendirme, yansıtma, mesleğe katk1 sağlama, eşitlik, adalet ve farklılıklara sayg1 olmak üzere 10 boyuttadır (NBPTS, 2012). Gelfer, Xu ve Perkins (2004) erken çocukluk eğitimcilerinin portfolyolarını düzenlerken, mesleki yeterliklerini planlama, öğretimi düzenleme, alan bilgisi, öğretmen-çocuk etkileşimleri, öğretmen-ebeveyn etkileşimleri, ölçme ve değerlendirme, sınıf yönetimi, program geliştirme, mesleki sorumluluklar ve mesleki gelişim alanlarında görünür kılmak adına belgelendirme yapmalarını önermişlerdir.

Öğretmenler mesleki gelişimlerini hangi boyutlar veya mesleki standart çerçevesi doğrultusunda belgelendireceklerine karar verdikten sonra bu doğrultuda öğretmen portfolyolarını geliştirmeye başlayabilirler. Bir öğretmen portfolyosunda bulunması önerilen unsurlar şunlardır; kapak sayfası, içindekiler listesi, otobiyografi, eğitim felsefesi, mesleki gelişim planı, mesleki gelişim kanıtları (ürünler), ürün açıklamaları ve yansıtmalar (Costantino \& De Lorenzo, 2009; Wiltz vd., 2013)

Kapak sayfası, okuyucu için bir ilk izlenim oluşturur. Kapak sayfasında öğretmenin ismiyle birlikte fotoğrafı ve kurum bilgisi de yer alabilir. Öğretmenin portfolyosu için belirleyeceği başlık ve kapak sayfasının şekilsel detayları portfolyoyu kişiselleştirmek için birer yoldur (Bullock \& Hawk, 2010; Wiltz vd., 2013). Kapağın ardından detaylı bir içindekiler listesine yer verilmeli, bu listede portfolyoda yer alan belgeler tanımlanmalıdır. İçindekiler listesi okuyucu için bir yol haritası niteliği taşır, geliştiren öğretmenin kendisi için ise daha düzenli bir profesyonel kanıt sistemi sağlar. İçindekiler listesinde ürünler ve yansıtmalar, portfolyo geliştirilirken temel alınan mesleki gelişim boyutları veya standart alanlarına göre gruplandırılmalıdır (Foster vd. 2007, Wiltz vd., 2013). Otobiyografi, öğretmenin kim olduğunu, öğretmenlik mesleğini yapma motivasyonunu, hayatındaki anlamlı etkinlikleri, eğitim süreçlerini, etkilendiği toplum, kültür ve aile yapısını, değerlerini, "iyi öğretmen" tanımını içermelidir. Eğitim felsefesi öğretmenin, eğitim ve çocuk gelişimine ilişkin sahip olduğu teorik alt yapıyla uygulamalarını nasıl ilişkilendirdiğini ve nitelikli eğitim algısını ifade ettiği anlatımdır. Eğitim felsefesi öğretmenin kariyeri boyunca deneyimleri doğrultusunda gelişecek bir yapıdır (Friedman, 2012). Mesleki gelişim planı, öğretmenin öz değerlendirmesi ile kısa ve uzun vadeli mesleki gelişim hedeflerini, bir diğer ifadeyle portfolyonun odaklandığı amaçları içerir (Costantino \& De Lorenzo, 2009). Amaçlar hem mesleki gelişim süreci hem de portfolyonun tasarımı için belirleyici bir rol oynar (Jones \& Shelton, 2011). Portfolyo geliştirilirken temel alınan mesleki gelişim boyutları veya standart alanları, portfolyonun yapılandırıldığı aşama olan mesleki gelişim planında da temel alınmalı, mesleki gelişim hedefleri söz konusu boyutlar doğrultusunda kategorize edilmelidir. Ürünler, ürün açıklamaları ve yansıtmalar ise portfolyonun dokümantasyon işlevinin gerçekleştirildiği unsurlardır ve mesleki gelişimin görünür kılınmasına hizmet ederler. Bu dokümantasyon unsurları seçilirken ve oluşturulurken, portfolyo amaçları için kritik öneme sahip olan ve bu amaçlar doğrultusunda öğretmenin gelişimini en iyi şekilde gösteren temel parçalara yer verilmelidir (Costantino \& De Lorenzo, 2009).

Öğretmen portfolyosu düzenlenirken geleneksel basılı öğretmen portfolyolarına alternatif olarak elektronik portfolyolar da kullanılmaktadır. Elektronik portfolyo, basılı portfolyo ile aynı amaca hizmet eden fakat dijital ortamda oluşturulan bir formdur. Elektronik portfolyo, içerik unsurlarını daha kolay ve hızlı bir şekilde toplama, kaydetme, yönetme ve saklama imkânı sunar. Ayrıca ses ve video kayıtları ile dijital fotoğraflar gibi ürünlerin dokümantasyonu için daha elverişlidir. Elektronik portfolyo öğretmenin mesleki gelişimine ilişkin kanıtları düzenlemesi, özetlemesi ve paylaşması için esneklik ve yaratıcılık alanı sağlar. Elektronik portfolyonun basılı portfolyoya kıyasla ulaşılabilirlik, yaratıcılık, taşınabilirlik, paylaşılabilirlik ve teknoloji konforu gibi avantajlarının yanı sıra öğretmenlerin yetersiz teknoloji becerileri, yetersiz teknik destek, yazılım, ekipman ve internet sağlayıcılarına erişim sorunu gibi dezavantajları da olabilir (Foster vd., 2007). 


\section{5. Öğretmen Portfolyosunun Erken Çocukluk Eğitimi Mesleki Gelişiminde Kullanımı}

Öğretmen eğitimi programları kapsamında erken çocukluk eğitimi öğretmen adayları üç amaç doğrultusunda portfolyo geliştirmektedir; mesleki gelişim için öğrenme sistemleri olarak, biçimlendirici ve sonuç değerlendirme için ve istihdam amacıyla kişinin öğretmenlik yeterliklerini göstermek için (Ntuli. Keengwe \& Kyei-Blankson, 2009). Öğretmen eğitimi programlarında, öğretmen adaylarının portfolyolarını elektronik ortamlarda geliştirmeleri, hem kullanım kolaylı̆̆ hem de teknolojik becerilerini desteklemesi nedeniyle giderek artan bir şekilde tercih edilmektedir. Özellikle erken çocukluk eğitimi alanındaki öğretmen adayları için ürünleri toplama, düzenleme, kaydetme, ürünlere ilişkin yansıtıcı düşünce geliştirme, öğretim elemanlarından geri bildirim isteme, kopyalama ve aktarma süreçlerinde elektronik ortamlar daha elverişli görünmektedir (Plaisir, Hachey \& Theilheimer, 2011).

Erken çocukluk eğitimi öğretmen adayları portfolyo geliştirme sürecine eğitim felsefelerini tanımlayarak başlamalıdır. Burada erken çocukluk eğitiminde öğrenme ve öğretme süreçleri ile küçük çocuklara ilişkin inançlarına yer vermeli, mesleki ideallerini betimlemeli, kuramsal bilgileriyle uygulamaları arasında bağlantılar kurmalıdır. Eğitim felsefesinin yanında kişisel ve mesleki bilgilerinin yer aldığı bir forma yer verilmelidir. Böyle bir form öğretmen adayının erken çocukluk eğitimi alanındaki tecrübeleri, yabancı dil bilgisi, mesleki kuruluş üyelikleri, elde ettiği başarılara veya özel bir yeteneğine ilişkin belgeler gibi tanıtıcı unsurlar içerebilir. Öğretmen adayları portfolyonun mesleki gelişimi gösteren ürünler ve yansıtmalar bölümünü geliştirmek üzere ise dahil oldukları öğretmen eğitimi programının program yeterliliklerini temel alabilirler. Böyle bir ilişkilendirme, öğretmen adaylarının geliştirdikleri portfolyonun, öğretmen eğitimi programı kapsamında edindikleri mesleki yeterlikleri kanıtlamasına olanak tanır (Wiltz vd., 2013). Hizmet öncesi öğretmen portfolyosu geliştirmenin bu aşamasında, öğretmen adaylarının öğrenim gördükleri lisans programının program yeterliliklerini incelemeleri ve erken çocukluk eğitimi alanına özgü söz konusu yeterlikleri karşılayacak mesleki gelişim çalışmalarını planlamaları gerekmektedir. Erken çocukluk eğitimi öğretmen adayları için program yeterlilikleri ile mesleki gelişim çalışmaları ve kanıtlarının ilişkilendirildiği örnek bir portfolyo içeriği Tablo 1'de sunulmuştur.

Tablo 1: Erken Çocukluk Eğitimi Öğretmen Adayları İ̧̧in Örnek Portfolyo İ̧̧eriği

\begin{tabular}{|c|c|c|}
\hline Örnek Program Yeterliliği & Örnek Portfolyo İçeriği & Örnek Ürün \\
\hline $\begin{array}{l}\text { Erken çocukluk eğitimi } \\
\text { alanına ilişkin alan } \\
\text { bilgisine sahiptir. }\end{array}$ & $\begin{array}{c}\text { Alan kitabı ve makale okumalarına } \\
\text { ilişkin notlar } \\
\text { Farklı erken çocukluk eğitim kurumları } \\
\text { ziyaretleri } \\
\text { Dersler kapsamında erken çocukluk } \\
\text { eğitimi yaklaşımlarına ilişkin geliştirilen } \\
\text { ödev ve raporlar }\end{array}$ & $\begin{array}{c}\text { Erken çocukluk eğitiminde } \\
\text { davranış yönetimi stratejilerine } \\
\text { ilişkin makale veya alan kitabı } \\
\text { bölümü, mesleğe başladığında } \\
\text { dikkat edilecek noktalara ilişkin } \\
\text { notlar } \\
\text { Kurum anaokulları, özel } \\
\text { anaokulları, ilkokula bağlı } \\
\text { anasınıfları ve kreşleri ziyaret } \\
\text { fotoğrafları, gözlem notları, kurum } \\
\text { yetkilileriyle yapılan görüşmelere } \\
\text { ilişkin notlar } \\
\text { Reggio Emilia, Montessori, High } \\
\text { Scope, Head Start, Waldorf, Bank } \\
\text { Street vb. erken çocukluk eğitimi } \\
\text { yaklaşımlarının karşılaştırıldığı bir } \\
\text { rapor }\end{array}$ \\
\hline
\end{tabular}


Tablo 1 (Devam) : Erken Çocukluk Eğitimi Öğretmen Adayları İçin Örnek Portfolyo İçeriği

Erken çocukluk eğitimi alanına ilişkin öğretim strateji, yöntem ve teknikleri ile ölçme ve değerlendirme bilgisine sahiptir.
Çeşitli öğretim yöntem ve teknikleri

kullanılarak öğretmen adayı tarafından geliştirilen öğretim planları

Öğretmen adayı tarafından geliştirilen çocuğu tanıma ve değerlendirme araçları

Gelişim ve öğrenmeyi değerlendirme süreçlerine ilişkin çeşitli çalıştay ve kurslara katılım

Gözlem, analoji, kavram haritası, deney gibi çeşitli öğretim yöntemlerinin kullanıldığı farklı fen etkinliği planları

Rubrik, gelişim kontrol listesi, gözlem formu, sıklık sayımı formu

Erken çocukluk eğitiminde gelişim ve öğrenmeyi değerlendirmek üzere çocuk portfolyolarının kullanımına ilişkin bir çalıştayın katılım belgesi

Erken çocukluk döneminde ahlak gelişimine ilişkin alanyazın taramas1

Erken çocukluk dönemi gelişim ve öğrenme özellikleri bilgisine sahiptir.
Gelişim alanlarına ilişskin gerçekleştirilen alanyazın taramaları ve hazırlanan raporlar

Gelişim ve öğrenme teorilerine ilişkin gerçekleştirilen alanyazın taramaları ve hazırlanan raporlar
Yapılandırmacı yaklaşım, sosyokültürel kuram ve ekolojik yaklaşımın erken çocukluk eğitimine yansımalarının

karşılaștırmalı olarak hazırlanan bir rapor
Covid-19 pandemisinin erken çocukluk eğitimine yansımalarının değerlendirildiği bir panelin katılım belgesi ve alınan notlar

Erken çocukluk eğitimi alanında güncel konulara ilişkin panel ve konferanslara katılım

alanıyla tanımlar, analiz eder, kanıtlara ve araştırmalara dayalı çözüm önerileri geliş̧irir.
Makale okumalarına ilişkin notlar

Öğretmen, eğitim yöneticileri, aileler ve çeşitli alan uzmanları ile görüşmeler

Eylem araştırmaları
Aile katılımı çalışmalarına ilişkin okul yöneticileri ve ailelerle yapılan görüşme kayıtları

Staj uygulamaları kapsamında öğrenme merkezlerinin etkililiğinin arttırılmasına yönelik gerçekleştirilen bir eylem araştırmasının raporu

Öğretmen adayının staj kapsamında uyguladı̆̆ı bir drama etkinliğinin tüm aşamalarını kapsayan bir video kaydı

Staj uygulamaları kapsamında yürütülen öğrenme süreçlerinin video kayıtları

\footnotetext{
Staj uygulamaları kapsamında çocukların öğrenme sürecinde geliştirdikleri ürünler

Yürütülen öğrenme süreçlerine ilişkin öğretim elemanlarının gözlem kayıtları ve geri bildirimleri Yansitıcı günlükler

Staj uygulamaları kapsamında çocukların gelişim ve öğrenmelerinin değerlendirildiği araçlar

Erken çocukluk eğitiminin özelliklerini ve ilkelerini gelişim özelliklerine, bireysel farklılıklarına uygun öğrenme ve öğretme stratejileri, yöntem ve tekniklerini uygular ve çok yönlü değerlendirir.
}

\begin{tabular}{c} 
Öğretmen adayının staj kapsamında \\
uyguladığı bir sanat etkinliğinde \\
çocukların geliştirdiği özgün ürün \\
örnekleri \\
Öğretmen adayının staj kapsamında \\
uyguladığı snıı yönetimi \\
stratejilerine ilişkin öğretim \\
elemanının geri bildirimleri \\
Öğretmen adayının staj \\
uygulamalarına ilişkin yazdığı \\
yansıtıcı günlükler \\
Öğretmen adayının staj \\
uygulamaları kapsamında \\
doldurduğu gelişim gözlem \\
formlarından örnekler \\
\hline
\end{tabular}


Tablo 1 (Devam) : Erken Çocukluk Eğitimi Öğretmen Adayları Iç̧in Örnek Portfolyo İçeriği

\begin{tabular}{|c|c|c|}
\hline \multirow{4}{*}{$\begin{array}{l}\text { Erken çocukluk eğitimi } \\
\text { prensiplerine uygun } \\
\text { olarak öğrenme ortamları } \\
\text { düzenler ve materyal } \\
\text { geliştirir. }\end{array}$} & & $\begin{array}{l}\text { Türkçe etkinliğinde kullanmak } \\
\text { üzere gelistirilen cubuk kuklalar }\end{array}$ \\
\hline & $\begin{array}{l}\text { Dersler ve staj uygulamaları kapsamında } \\
\text { geliștirilen materyaller }\end{array}$ & \multirow{3}{*}{$\begin{array}{c}\text { El-göz koordinasyonunu } \\
\text { desteklemek üzere gelisțirilen bir } \\
\text { labirent oyuncağını çocukların nas1 } \\
\text { kullandığına ilişkin gözlem } \\
\text { kayıtları } \\
\text { Öğretmen adayının staj } \\
\text { uygulamaları kapsamında } \\
\text { gerçekleştirdiği bir hareket etkinliği } \\
\text { için hazırladığı parkurun } \\
\text { fotoğrafları }\end{array}$} \\
\hline & $\begin{array}{l}\text { Çocukların geliştirilen materyalleri } \\
\text { kullanımlarına ilişskin gözlemler }\end{array}$ & \\
\hline & $\begin{array}{l}\text { Staj uygulamaları kapsamında } \\
\text { düzenlenen öğrenme ortamlarının } \\
\text { fotoğrafları }\end{array}$ & \\
\hline \multirow{3}{*}{$\begin{array}{l}\text { Toplumsal sorumluluk } \\
\text { bilinciyle yaşadığı sosyal } \\
\text { çevre için mesleki proje ve } \\
\text { etkinlikler planlar, } \\
\text { uygular. }\end{array}$} & Mesleki kuruluşlara üyelik & \multirow{3}{*}{$\begin{array}{l}\text { Türkiye Okul Öncesi Eğitimini } \\
\text { Geliştirme Derneği'ne üyelik kaydı } \\
\text { Topluma Hizmet Uygulamaları } \\
\text { dersi kapsamında bir anaokulu için } \\
\text { materyal geliştirme çalışmalarına } \\
\text { ilişkin fotoğraflar ve yansıtıcı } \\
\text { günlükler }\end{array}$} \\
\hline & $\begin{array}{c}\text { Geliştirilen mesleki projelere ilişskin } \\
\text { raporlar }\end{array}$ & \\
\hline & $\begin{array}{l}\text { Mesleki projelerde alınan görevlere } \\
\text { ilişkin yansitıcı günlükler, katılım } \\
\text { belgeleri, broşürler, fotoğraf ve videolar }\end{array}$ & \\
\hline
\end{tabular}

Hizmet içi öğretmenlerin mesleki gelişim amacıyla geliştirecekleri portfolyolar, öğretmen adaylarının portfolyolarına benzer şekilde, öncelikle eğitim felsefesi ile kişisel ve mesleki profil unsurlarını içermelidir. Eğitim felsefesinde öğretmenin bir erken çocukluk eğitimcisi olarak kendisini nasıl tanımladığı, meslek olarak neden erken çocukluk eğitimi alanını seçtiği, çocukların öğrenme süreçlerine ilişkin inanışlarının neler olduğu, hangi öğretim yöntem ve tekniklerini etkili bulduğu, daha iyi bir öğretim için neler yapılabileceği, erken çocukluk eğitiminde aile ve toplumun rolünün ne olduğu gibi soruların cevapları, öğretmenin uygulamalarıyla ilişkili bir şekilde yer almalıdır. Eğitim felsefesi, öğretmenin günlük uygulamalarının ardındaki teorik gerekçeleri açıklaması bakımından önem taşır (Jones ve Shelton, 2011; Wiltz vd., 2013). Bunun yanında, öğretmenlerin bireysel mesleki gelişim planlarını portfolyolarına eklemeleri, portfolyonun amaçlarını belirleme ve içeriğini yapılandırma için gereklidir. Görev yapan erken çocukluk eğitimi öğretmenleri, portfolyolarını mesleki yeterlikler doğrultusunda geliştirmelidirler ve Öğretmenlik Mesleği Genel Yeterlikleri'ni (MEB, 2017) mesleki gelişim hedeflerini ve portfolyo içeriklerini ilişkilendirmek için temel alabilirler. Erken çocukluk eğitimi öğretmenleri için Öğretmenlik Mesleği Genel Yeterlikleri (MEB, 2017) ile mesleki gelişim çalışmaları ve kanıtlarının ilişkilendirildiği örnek bir portfolyo içeriği Tablo 2'de sunulmuştur. 
Tablo 2: Erken Çocukluk Eğitimi Öğretmenleri İ̧̧in Örnek Portfolyo İ̧̧eriği

\begin{tabular}{|c|c|c|}
\hline $\begin{array}{c}\text { Öğretmenlik Mesleği } \\
\text { Genel Yeterlikleri } \\
\text { (MEB, 2017) }\end{array}$ & Örnek Portfolyo İçeriği & Örnek Ürün \\
\hline \multirow{5}{*}{ Alan bilgisi } & \multirow{5}{*}{$\begin{array}{l}\text { Mesleki okumalara ilişkin notlar } \\
\text { Mesleki uygulamalarının temelindeki } \\
\text { gelişim ve öğrenme teorileri ile erken } \\
\text { çocukluk eğitimi yaklaşımlarını } \\
\text { açıklayan yansıtıcı günlükler } \\
\text { Farklı gelişim alanlarını destekleme } \\
\text { uygulamalarına ilişkin örnekler }\end{array}$} & $\begin{array}{c}\text { Çevre eğitimine ilişkin yapılan } \\
\text { okumalardan notlar }\end{array}$ \\
\hline & & $\begin{array}{l}\text { Öğretmenin bireysel farkl1lıkları } \\
\text { gözeterek ve sosyal öğrenme }\end{array}$ \\
\hline & & $\begin{array}{l}\text { kuramına dayanarak düzenlediği } \\
\text { küçük grup etkinliklerinde yansitıcı } \\
\text { raporlar }\end{array}$ \\
\hline & & Bilişsel gelişimi desteklemek üzere \\
\hline & & $\begin{array}{l}\text { bir sınıf rutini olarak yap-boz } \\
\text { gününe ilişkin fotoğraflar, sıklık } \\
\text { sayımları, çocukların basitten zora } \\
\text { doğru çalışıtıları materyallere } \\
\text { ilişkin kayıtlar }\end{array}$ \\
\hline \multirow{5}{*}{ Alan eğitimi bilgisi } & $\begin{array}{c}\text { Uygulanan öğretim programına ilişkin } \\
\text { değerlendirmeler }\end{array}$ & $\begin{array}{l}\text { Okul Öncesi Eğitim Programı'nda } \\
\text { yer alan serbest oyun zamanına } \\
\text { ilişkin öğretmenin deneyimlerini } \\
\text { açıklayan yansıtıcı günlükler }\end{array}$ \\
\hline & Program geliştirme çalışmalarını takip & $\begin{array}{l}\text { Erken çocukluk eğitiminde } \\
\text { teknolojik materyallerin }\end{array}$ \\
\hline & $\begin{array}{l}\text { Farklı disiplinler ile erken çocukluk } \\
\text { eğitiminin ilişkilendirildiği projeler }\end{array}$ & $\begin{array}{l}\text { kullanımının değerlendirildiği bir } \\
\text { proje denevimine iliskin yansıtıcı }\end{array}$ \\
\hline & \multirow{2}{*}{$\begin{array}{c}\text { Erken çocukluk eğitiminde güncel } \\
\text { konulara ilişkin eğitim etkinliklerine } \\
\text { katıllım }\end{array}$} & günlükler, fotoğraflar \\
\hline & & $\begin{array}{l}\text { Çocuklar İçin Felsefe (P4C) konulu } \\
\text { atölye çalışmasına ilişkin katılım } \\
\text { belgesi, sınıf içi uygulamalardan } \\
\text { fotoğraflar ve etkinlik planları }\end{array}$ \\
\hline \multirow{2}{*}{ Mevzuat bilgisi } & $\begin{array}{l}\text { Erken çocukluk eğitimi alanındaki } \\
\text { eğitim politikalarına ilişsin } \\
\text { değerlendirmeler }\end{array}$ & $\begin{array}{l}\text { Güncellenen politika belgelerine } \\
\text { ilişsin yansıtıcı günlükler }\end{array}$ \\
\hline & $\begin{array}{c}\text { Özel gereksinimli çocukların haklarının } \\
\text { düzenlendiği politikalara ilişkin } \\
\text { değerlendirmeler }\end{array}$ & \\
\hline \multirow{4}{*}{$\begin{array}{l}\text { Eğitim öğretimi } \\
\text { planlama }\end{array}$} & Aylık planlar & Aylık plan örneği \\
\hline & Günlük akış & Günlük akış örneği \\
\hline & $\begin{array}{l}\text { Çeşitli etkinlik türleri, gruplama } \\
\text { stratejileri, ve ögrretim yöntem - } \\
\text { teknikleri kullanılarak geliştirilen } \\
\text { etkinlik planları }\end{array}$ & $\begin{array}{c}\text { Fen, matematik, oyun, Türkçe, } \\
\text { hareket, müzik, alan gezisi } \\
\text { etkinliklerine ilisskin örnek etkinlik } \\
\text { planları }\end{array}$ \\
\hline & $\begin{array}{l}\text { Kazanım, gösterge ve kavramlara ilişkin } \\
\text { takip çizelgeleri }\end{array}$ & $\begin{array}{l}\text { Aile katılımı bölümlerinin yer } \\
\text { aldığ } 1 \text { etkinlik planları }\end{array}$ \\
\hline
\end{tabular}


Tablo 2 (Devam): Erken Çocukluk Eğitimi Öğretmenleri Iç̧in Örnek Portfolyo İ̧̧eriği

\begin{tabular}{cc}
\hline & Öğrenme merkezlerinin kullanımı ve \\
geliştirilmesine ilişkin kanıtlar \\
Alan gezilerine ve doğal öğrenme \\
ortamlarının kullanımına ilişkin \\
planlar, fotoğraflar ve çocukların geri \\
bildirimleri \\
Geliştirilen materyaller \\
$\begin{array}{c}\text { Öğrenme ortamları } \\
\text { oluşturma }\end{array}$ \\
Çocukların materyal ve öğrenme \\
merkezi kullanımına ilişkin \\
değerlendirmeleri \\
Eylem araştırmaları
\end{tabular}

Öğrenme merkezlerinin

güncellenmesine ilişkin öncesisonrası fotoğrafları

Müze gezisi fotoğrafları, alan gezisinde çocuklara dağıtılan müze

krokisi örneği, müzede öğrenme sürecinin odaklandığı eserin fotoğrafi ve esere ait bilgiler, çocukların müze gezisine ilişkin geri bildirimleri ve çizimleri

Çocukların bilimsel süreç becerilerini desteklemek üzere okul bahçesinde sebze yetiştirmeyi içeren bir eylem araştırması raporu

Sınıf kurallarına ilişkin görseller, istenmeyen davranışları yönetme stratejilerine ilişkin kanıtlar, davranış

Sınıf yönetimi stratejileri

Öğretme ve öğrenme sürecini yönetme

Kullanılan çeşitli öğretim yöntem ve teknikleri

Aile katılımı çalışmaları

Eylem araştırmaları

sıklık sayımları, zaman yönetimine ilişkin çizelgeler

Drama, öyküleştirme, müzikle ögretim, kavram haritası, oyun temelli öğrenme, beyin firtınası gibi çeşitli yöntem tekniklerin kullanıldığı etkinlik planları, etkinlik videoları

Aile katılımı çalışmalarına ilişkin fotoğraflar ve değerlendirmeler

Bir çocuğa ilişkin yıl boyunca elde edilen değerlendirme verisinin tamamı

Dil gelişimini değerlendirmeye yönelik bir standart testin uygulayıc1 eğitimine ilişkin katılım belgesi ve uygulanmış bir test örneği

Kontrol listeleri ve rubrikler

Kullanılan standart testler

Çocuklar arasında eşitlik ve adalet sağlamak adına alınan önlemler

Millî, manevi ve evrensel değerler

Öğretmenin sınıftaki çeşitliliği nasıl

değerlendirdiğine ilişkin yansıtıcı günlükler

Mesleki etikle ilgili uygulamalar
Öğretmenin çocuklar arasında eşitlik ve adalet sağlamaya çalışırken ikilem yaşadığı durumlara ilişkin yansıtıcı günlükler, bulduğu çözümler

Öğretmenin özel gereksinimli bir çocuğun sınıfa uyumunu sağlamaya çalışırken aldığı önlemleri açıkladığı yansitıcı günlükler

Öğretmen-çocuk etkileşimine ilişkin

Öğretmen-çocuk etkileşimi kanıtları

Öğretmenin bireysel farklılıklara ilişkin katıldığı eğitimler, mesleki okumaları, yansıtıcı günlükleri ses kayıtları, anekdot kayıtları, video kayıtları, paydaş gözlemleri

Otizm tanılı çocuklarla iletişime

ilişkin bir konferansın katılım belgesi, konferansta sorulan sorular ve alınan notlar 
Tablo 2 (Devam): Erken Çocukluk Eğitimi Öğretmenleri Iç̧in Örnek Portfolyo İ̧̧eriği

\begin{tabular}{|c|c|c|}
\hline \multirow{5}{*}{ İletişim ve iş birliği } & \multirow{5}{*}{$\begin{array}{c}\text { Aile eğitimi çalışmaları } \\
\text { Ailelerle iletişim örnekleri } \\
\text { Meslektaşlarla işbirlikli proje çalışmaları } \\
\text { Toplum kaynaklarıyla iş birliği kanıtları }\end{array}$} & $\begin{array}{l}\text { Mahremiyet eğitimine ilişkin bir } \\
\text { aile eğitimi planı, eğitime ait } \\
\text { fotoğraflar, ailelerin eğitime } \\
\text { ilişkin yazılı geri bildirimleri }\end{array}$ \\
\hline & & Aile toplantıları kayıtları, aile \\
\hline & & \\
\hline & & $\begin{array}{c}\text { ortamlarda gerçekleştirilen } \\
\text { etkileşimler vb. }\end{array}$ \\
\hline & & $\begin{array}{c}\text { eTwinning projelerinin raporları, } \\
\text { uygulama fotoğrafları }\end{array}$ \\
\hline \multirow{5}{*}{ Kişisel ve mesleki gelişim } & Mesleki kuruluşlara üyelik & \multirow{5}{*}{$\begin{array}{c}\text { Eğitimde İyi Örnekler } \\
\text { Konferansına katılım yoluyla } \\
\text { etkili uygulamaları meslektaşlarla } \\
\text { paylaşım. Konferans fotoğrafları, } \\
\text { broşürler ve katılım belgesi } \\
\text { Gitar kursuna katılım, çocuk } \\
\text { şarkılarının çalındığı videolar, } \\
\text { katılım belgesi }\end{array}$} \\
\hline & $\begin{array}{c}\text { Geliştirilen mesleki projelere ilişkin } \\
\text { raporlar }\end{array}$ & \\
\hline & $\begin{array}{c}\text { Erken çocukluk eğitimi alanında liderlik } \\
\text { gösterilen calısmalar }\end{array}$ & \\
\hline & $\begin{array}{l}\text { Kişisel ilgi alanları doğrultusunda alınan } \\
\text { eğitimler ve yapılan uygulamalar }\end{array}$ & \\
\hline & Lisansüstü eğitimler & \\
\hline
\end{tabular}

Sonuç olarak, öğretmen portfolyosu erken çocukluk eğitimcilerinin kendi mesleki gelişim ihtiyaçlarını öz değerlendirme yoluyla tespit etmelerine, söz konusu ihtiyaçlarını karşılamak üzere gerçekleştirecekleri mesleki gelişim çalışmalarını kendi ilgileri ve koşulları doğrultusunda planlamalarına, yürüttükleri mesleki gelişim çalışmalarını ürün ve yansıtmalarla belgelendirerek değerlendirmelerine olanak sağlayan bir mesleki gelişim aracıdır. Öğretmen portfolyosu aracılığıyla yürütülen mesleki gelişim süreçleri erken çocukluk eğitimcilerinin, kendi mesleki gelişimlerinin sorumluluğunu alan, karar verici, özerk ve mesleki gelişimlerinde aktif bir rol almalarını sağlar. Bu bağlamda öğretmen portfolyosu eğitimcilerin yeterliklerini güçlendirerek ve mesleki gelişim döngüsünün sürekliliğini sağlayarak eğitimin niteliğinin artması bakımından değerli bir araç olma özelliğini taşımaktadır. 


\section{KAYNAKLAR}

Aras, S. (2019). Action research and teacher portfolio as two strong teacher-led professional development designs. P. D. Keough (Ed.), Overcoming Current Challenges in the P-12 Teaching Profession (ss. 51-71) içinde. IGI Global. https://doi.org/10.4018/978-1-7998-1177-0

Aras, S. (2021) A case study on teacher portfolio with early childhood teachers, Reflective Practice, 22(2), 219232.

Buldu, M., \& Üstebay Aras, S. (2014). Öğretmen mesleki gelişimi planlaması ve dokümantasyonu. Öğretmen Dünyasl, 414, 22-25.

Bullock, A.A., \& Hawk, P.P. (2010). Developing a teaching portfolio: a guide for preservice and practicing teachers (3. Bask1). Pearson.

Bümen, N.T., Ateş, A., Çakar, E., Ural, G., Acar, V. (2012). Türkiye bağlamında öğretmenlerin mesleki gelişimi: sorunlar ve öneriler. Millî Eğitim, 194, 31-49.

Can, E. (2019). Öğretmenlerin meslekî gelişimleri: Engeller ve öneriler. Eğitimde Nitel Araştırmalar Dergisi Journal Of Qualitative Research In Education, 7(4), 1618-1650.

Campbell, D.M., Melenyzer, B.J., Nettles, D.H., \& Wyman, R.M. (2014). How to develop a professional portfolio I a manual for teachers. Pearson.

Chetcuti, D., Buhagiar, M. A., \& Cardona, A. (2011). The professional development portfolio: Learning through reflection in the first year of teaching. Reflective Practice, 12(1), 61-72.

Costantino, P.M., \& De Lorenzo, M.N., (2009). Developing a professional teaching portfolio / a guide for success (3. Bask1). Pearson.

Creemers, B., Kyriakides, L., \& Antoniou, P., (2013). Teacher professional development for improving quality of teaching. Springer. https://doi.org/10.1007/978- 94-007-5207-8

Darling Hammond, L., \& McLaughlin, M. W. (2011). Policies that support professional development in an era of reform. Kappan Classic, 92(6), 81-92.

Darling Hammond, L., Hyler, M.E., \& Gardner, M. (2017). Effective teacher professional development. Palo Alto, CA: Learning Policy Institute.

Desimone, L. M. (2009). Improving impact studies of teachers' professional development: toward better conceptualizations and measures. Educational Researcher, 38(3), 181-199.

Dinham, S., \& Scott, C. (2003). Benefits to teachers of the professional learning portfolio: a case study. Teacher Development, 7(2), 229-244.

Diaz-Maggioli, G. (2004). Teacher-centered professional development. Association for Supervision and Curriculum Development - ASCD.

Elçiçek, Z., Yaşar, M. (2016). Türkiye'de ve dünyada öğretmenlerin mesleki gelişimi. Elektronik Eğitim Bilimleri Dergisi, 5(9), 12-19.

Elliott, B. (2002). Measuring performance the early childhood educator in practice. Delmar Thomson Learning.

Evans, L. (2002). What is teacher development. Oxford Review of Education, 28(1), 123-137.

Foster, B.L., Walker, M. L., \& Song, K. H. (2007). A beginning teaching portfolio handbook: documenting and reflecting on your professional growth and abilities. Pearson.

Friedman, D.L. (2012). Creating and presenting an early childhood education portfolio: a reflective approach. Wadsworth Cengage Learning.

Garcia, M., Sanchez, V., \& Escudero, I. (2006). Learning through reflection in mathematics teacher education. Educational Studies In Mathematics, 64, 1-17.

Gelfer, J. I., Xu, Y., \& Perkins, P. G. (2004). Developing portfolios to evaluate teacher performance in early childhood education. Early Childhood Education Journal, 32(2), 127-132.

Goodfellow, J. (2004). Documenting professional practice through the use of a professional portfolio. Early Years, $24(1), 63-74$ 
Griffith, P. L., Ruan, J., Stepp, J., \& Kimmel, S. J. (2014). The design and implementation of effective professional development in elementary and early childhood settings. L. E. Martin, S. Kragler, D. J. Quatroche, \& K. L. Bauserman (Ed.), Handbook of Professional Development in Education /Successful Models and Practices, PreK-12 (s. 189-204) içinde. The Guilford Press.

Guskey, T.R. (2000). Evaluating professional development. Corwin Press.

Guskey, T.R. (2003). What makes professional development effective? Phi Delta Kappan, 84(10), 748-750.

InTASC, (2013). InTASC model core teaching standards and learning progressions for teachers 1.0. CCSSOCouncil of Chief State School Officers.

İlğan, A. (2013). Öğretmenler için etkili mesleki gelişim faaliyetleri. Uşak Üniversitesi Sosyal Bilimleri Dergisi, Özel Sayl, 41-56.

Janssen, S., Kreijns, K., Bastiaens, T., Stijen,S., \& Vermeulen, M. (2012). Teachers' professional development: an analysis of the use of professional development plans in a Dutch school. Professional Development in Education, 38(3), 453-469.

Jones, M., \& Shelton, M., (2011). Developing your portfolio: enhancing your learning and showing your stuff. A guide for the early childhood student or professional (2. Bask1). Routledge.

Kaplan, M. (1999). The teaching portfolio. Center for Research on Learning and Teaching Occaional Papers.

Lieberman, A. (1995). Practices that support professional development: transforming conceptions of professional learning. Phi Delta Kappan, 76, 591-596.

Louws, M. L., Meirink, J. A., Veen, K., \& Driel, J. H. (2018). Understanding teachers' professional learning goals from their current professional concerns. Teachers and Teaching: Theory and Practice, 24(1), 63-80.

Martinez-Beck, I., \& Zaslow, M. (2006). The context for critical issues in early childhood professional development. M. Zaslow, \& I. Martinez-Beck (Ed.), Critical Issues in Early Childhood Professional Development (s. 1-17) içinde. Paul H Brookes Publishing Co.

MEB (2017). Öğretmenlik mesleği genel yeterlikleri. http://oygm.meb.gov.tr/meb_iys_dosyalar/2017_12/11115355_YYRETMENLYK_MESLEYY_GENEL_ YETERLYKLERY.pdf

Mraz, M., \& Kissel, B. (2014). Professional development in early childhood education: models and recommendations. L. E. Martin, S. Kragler, D. J. Quatroche, \& K. L. Bauserman (Ed.), Handbook of Professional Development in Education/Successful Models and Practices, PreK - 12 (s. 174-188) içinde. The Guilford Press.

MSF Ministry of Social and Family Development (t.y.). Achieving excellence through continuing professional development: a CPD framework for early childhood educators. https://www.earlychildhoodworkforce.org/sites/default/files/resources/CPD_Guide_5_FA.pdf adresinden 26.03.2016 tarihinde erişilmiş̧tir.

NAEYC, (2011). 2010 NAEYC standards for initial \& advanced early childhood professional preparation programs.

https://www.naeyc.org/sites/default/files/globally-shared/downloads/PDFs/accreditation/higher-ed/naeychigher-ed-accreditation-standards.pdf

NAEYC \& NACCRRA (2011). Early childhood education professional development training and technical assistance glossary.

11/GlossaryTraining_TA.pdf

NBPTS (2012). National board for professional teaching standards early childhood generalist standards (3. Bask1). https://www.nbpts.org/wp-content/uploads/2017/07/EC-GEN.pdf

North Carolina Institute (2001). Planning for professional development in child care: a guide to best practices and resources. http://ncicdp.org/documents/best.pdf

Ntuli, E., Keengwe, J., Kyei-Blankson, L. (2009). Electronic portfolios in teacher education: a case study of early childhood teacher candidates. Early Childhood Education Journal, 37, 121-126.

Patton, K., Parker, M., \& Tannehill, D. (2015). Helping teachers help themselves: professional development that makes a difference. NASSP Bulletin, 99(1), 26-42. 
Paul, M., (2004). Teaching and learning portfolios: thoughtfully presenting yourselffor a successful faculty career a guidebook. Delta Integrating Research, Teaching, and Learning.

Peeters, J., Backer, F. D., Reina, V.R., Kindekens, A., Buffel, T., \& Lombaerts, K. (2014). The role of teachers' self-regulatory capacities in the implementation of self-regulated learning practices. Social and Behavioral Sciences, 116, 1963-1970.

Plaisir, J. Y., Hachey, A. C., Theilheimer, R. (2011). Their portfolios, our role: examining a community college teacher education digital portfolio program from the students' perspective. Journal of Early Childhood Teacher Education, 32, 159-175.

Ross, J. A., \& Bruce, C. D. (2007). Teacher self-assessment: a mechanism for facilitating professional growth. Teaching and Teacher Education, 23, 146-159.

Seldin, P., Miller, J. E., \& Seldin, C. A. (2010). The teaching portfolio: a practical guide to improved performance and promotion / tenure decisions. Jossey - Bass.

Sheridan, S.M., Edwards, C.P., Marvin, C.A., \& Knoche, L.L. (2009). Professional development in early childhood programs: process issues and research needs. Early Education and Development, 20(3), 377-401.

Smith, K., \& Tilemma, H. (2010). Long-term influences of portfolios on professional development. Scandinavian Journal of Educational Research, 45 (2), 183-203.

Stacy, M. (2013). Teacher-led professional development: empowering teachers as self-advocates. The Georgia Social Studies Journal, 3(1), 40-49.

Sugarman, N. (2011). Putting yourself in action individual professional development plans. Young Children, 66(3), 27-33.

Sultana, R.G. (2009). Competence and competence frameworks in career guidance: complex and contested concepts. International Journal for Educational and Vocational Guidance, 9, 15-30.

Tucker, P., Stronge, J., \& Gareis,C. (2002). Handbook on teacher portfolios for evaluation and professional development. Eye on Education.

Van Eekelen I.M., Boshuizen, H.P.A., \& Vermunt, J.D. (2005). Self regulation in higher education teacher learning. Higher Education, 50, 447-471.

Villegas-Reimers E. (2003). Teacher professional development: an international review of the literature. UNESCO International Institute for Educational Planning.

Youngs, P., \& Lane, J. (2014). Involving teachers in their own professional development. L. E. Martin, S. Kragler, D. J. Quatroche, \& K. L. Bauserman (Ed.), Handbook of Professional Development in Education /Successful Models and Practices, PreK - 12 (s. 284-303) içinde. The Guilford Press.

Zaslow, M., Tout, K., Halle, T., Whittaker, J.V., \& Lavelle, B. (2010). Toward the identification of features of effective professional development for early childhood educators: literature review. U.S. Department of Education Office of Planning, Evaluation and Policy Development Policy and Program Studies Service.

Wells, M. (2014). Elements of effective and sustainable professional learning. Professional Development in Education, 40(3), 488-504.

Westhuizen, G.J., \& Smith, K. (2000). Teachers' portfolio reflections: a comparative analysis. Teacher Development, 4(3), 339-352.

Wiltz, N. W., Daniels, J., Skelley, H.A., Cawley, H.S., \& Watson-Thompson, O. (2013). Developing and presenting a professional portfolio in early childhood education. Pearson.

Wray, S. (2004). Navigating the portfolio process within a teacher learning community. [Yayımlanmamış Doktora Tezi]. University Of Wisconsin-Madison. 


\section{EXTENDED ABSTRACT}

Early childhood educators are expected to have a deep understanding of child development and early childhood education in order to provide all children with rich educational experiences, to engage with children with diverse abilities and past experiences, and to connect with families of various characteristics (Sheridan et al., 2009). Professional development is essential in the early childhood education workforce to provide quality early childhood education services to children and families (NAEYC \& NACCRRA, 2011).

In recent years, research has focused on the concept of effective professional development as a new paradigm that offers strong opportunities for teachers' professional learning and deviates from the traditional model. Effective professional development is structured professional learning processes that result in changes in teachers' knowledge, practices and learner outcomes (Darling-Hammond et al., 2017). Darling-Hammond et al. (2017) stated that the principles of effective professional development are content focus, active learning based on adult education theories, cooperation in an embedded context, effective practice examples, coaching and expert support, feedback and reflection, and sustainability.

Effective professional development places teachers in a more active role in their professional learning processes by removing them from the passive role placed by traditional professional development approach (Youngs \& Lane, 2014). The teacher-led professional development process, in which teachers take an active role in their own professional development processes, includes the stages of planning, making visible and evaluating (Janssen et al., 2012; Peeters et al., 2014; Van Eekelen et al., 2005). The teacher portfolio appears to be an effective professional development tool in teachers' teacher-led professional development process by following these stages (Aras, 2019; Janssen et al., 2012).

A teacher portfolio is a collection of documents that provide evidence for teachers' knowledge, skills and attitudes, organized and brought together in line with specific goals (Costantino \& De Lorenzo, 2009). Teachers 'portfolio is not teachers' collecting documents and materials related to their own performance as an archive, but a careful selection and presentation of reliable evidence regarding the quality of teaching processes (Kaplan, 1999; Bullock \& Hawk, 2010; Paul, 2004). Portfolio enables teachers to reflect on practical experiences and to carry out reflection practices by encouraging the expression of professional knowledge (Chetcuti et al., 2011).

The teacher portfolio puts the responsibility on teachers for their own learning and helps them identify how they define themselves as learners. It also provides teachers with the opportunity to reflect their theoretical background in their professional practice and supports the broadening of teachers' perspectives on education. Another benefit of the teacher portfolio is that it provides permanent and meaningful professional learning, free from rote learning. In this process, teachers experience trial and error, establish dialogues with their colleagues, and think and question what they know, how they learn and how they affect them. Finally, the portfolio development process strengthens functional thinking skills such as metacognition, abstract and complex thinking, and theoretical reasoning. These cognitive skills play a role in teachers' internalizing their professional learning and developing higher level skills. (Jones \& Shelton, 2011).

The teacher portfolio fulfills the functions of planning, documentation and evaluation in teacher professional development. Teachers plan their professional development processes as autonomous learners while developing portfolios; They determine the content, framework and goals of their professional work themselves (Campbell et al., 2014; Costantino \& De Lorenzo, 2009). Professional development plan is a document that teachers create and constantly review and update, that will guide their future professional development (Sugarman, 2011). Documentation of the process is as important 
as its planning and implementation in order to ensure the effectiveness of professional development activities (Buldu \& Üstebay Aras, 2014). Systematic documentation with the teacher portfolio enables teachers to be more conscious about their own practices and reflect on their previous practices (Aras, 2019), and also makes possible to understand the difficulty of professional practices (Goodfellow, 2004). The two main documentation elements in an effective teacher portfolio are evidence of practice and reflective statements (Paul, 2004). When teachers choose products or reflect on their work in the portfolio creation process, they naturally enter the evaluation process by reviewing these products (Friedman, 2012). The portfolio provides multiple sources of data overlooked in traditional assessment methods and is a highly specific assessment tool for teacher's development and learning (Costantino \& De Lorenzo 2009).

In order to organize an effective teacher portfolio, two dimensions should be addressed, namely the competencies to be associated with the portfolio content and the elements that should be included in the portfolio content (Tucker et al., 2002). Professional competence areas and steps are important in understanding the levels of professional development and specialization steps, it enables the systematic organization of professional development, supports teachers to analyze areas open to improvement, and improves their self-monitoring skills (Sultana, 2009). The elements suggested to be included in a teacher portfolio are as follows; cover page, table of contents, autobiography, educational philosophy, professional development plan, professional development evidence (products), product descriptions and reflections (Costantino \& De Lorenzo, 2009; Wiltz et al., 2013).

There are various types of portfolios developed by pre-service teachers and in-service teachers. (Costantino \& De Lorenzo, 2009). The teacher portfolio development process enables preservice teachers to understand the profession, develop self-awareness, design career development, and holistic and authentic evaluation processes. For in-service teachers, the teacher portfolio is a tool to change the teaching style being carried out (Campbell et al., 2014).

As a result, the teacher portfolio is a professional development tool that allows early childhood educators to identify their own professional development needs through self-assessment, to plan their professional development studies to meet these needs in line with their own interests and conditions, and to evaluate their professional development studies by documenting them with products and reflections. Professional development processes carried out through the teacher portfolio, gives early childhood educators to take responsibility for their own professional development, to make decisions, being autonomous and to take an active role in their professional development. In this context, the teacher portfolio is a valuable tool in terms of increasing the quality of education by strengthening the competencies of educators and ensuring the continuity of the professional development cycle. 